\title{
UDC 329.8:159.937.515.5
}

\section{Mykola Primush} Ukraine),

Doctor of Political Sciences, Professor, Vasyl Stus Donetsk National University (Vinnytsa,

e-mail: m.Prymush@donnu.edu.ua

\section{SYMBOLIC AND PARTY IMAGE OF POLITICAL PARTIES}

\begin{abstract}
The presented scientific research is devoted to the analysis of factors of influence of symbols of political party on her development and political rhetoric. The emphasis is placed on studying of symbols and the political choice of voters. It is proved that the party symbolics can act as the communication medium between parties and her voter. The scientific facts according to which the political symbolics and party colors bear in themselves sense of a party course of heads of political parties are offered and also display understanding of a role of party in political life of society. Factors of development of political symbolics in Ukraine are offered. Detailed studying of foreign experience has shown that the party symbolics has the logical and symbolical nature. The first shows her historical roots and serves as the political bridge between ideals and values of generations. The second aspect, symbolical — is continuation of the first, but bears in itself nonverbal sense. The essence consists that the political party, enduring certain stages of social and political development of the state, tries to display them in the political symbols, the name, flowers. It becomes not only for mass influence on the choice of electorate and also with the purpose to become main using the force political capable to be on one wave with the voter. Also, in a research it is shown that in the Ukrainian political practice this aspect is given a certain attention, but in general — party heads use opposite symbols and their values.
\end{abstract}

Keywords: political party, party symbolic, political policy of party, political system, functions of political parties. 


\section{УДК 329.8:159.937.515.5}

\section{Примуш Микола Васильович} Україна)

Доктор політичних наук, профессор, Донецький національний університет (м. Вінниця,

e-mail: m.Prymush@donnu.edu.ua

\section{СИМВОЛІКА ТА ПАРТІЙНИЙ ІМІДЖ ПОЛІТИЧНИХ ПАРТІЙ}

\section{Резюме}

Дослідження присвячено аналізу технологій побудови іміджу сучасних політичних партій, їх стратегії розвитку крізь призму вивчення сенсу їх символіки та кольорів. У дослідженні партійна символіка подається як важливий засіб комунікації між політичними партіями та ії виборцями. Доведено, що політична символіка та партійні кольори несуть у собі сенс партійного курсу керівників політичних партій, а також відображають їх розуміння ролі партії в політичному житті.

Ключові слова: партійна партія, партійна символіка, політичний курс партії, політична система, функції політичних партій.

\section{1. Ветуп}

Актуальність представленого дослідження полягає у тому, що науковий аналіз теорії політичних партій в Україні можна поділити на 4 провідні групи. Першу таку групу складають дослідження передусім теоретико-методологічного характеру, де мова йде про поняття, роль та функції політичних партій в умовах сучасної України. Друга група досліджень ставить своїм заданням адоптацію зарубіжних теоретичних напрацювань у практичну площину в умовах України. Третя група досліджень аналізує специфіку виборчого процесу та участь в ньому політичних партій. I нарешті, четверта група розглядає політичні партії у контексті їх взаємодії з інститутами політичної системи. Разом з тим, у країнах сталої демократії набирає популярності дослідження будівництва, управління та участі політичних партій у політичному житті 3 позицій соціоністичного підходу. Мова йде про те, що будь-яка політична партія має певну символіку, яка у свою чергу відображає іiі політичні, ціннісні та соціальні орієнтації у вигляді не тільки логотипів, кольорів, а також створює у психології виборця певну асоціацію та уявлення про певну політичну силу. Складність подібних досліджень криється у розмежуванні таких категорій як синестетика (вивчення впливу кольору на електоральний вибір), іміджелогія (побудування певних управлінських стратегій з метою конструювання позитивного уявлення про предмет дослідження) та власно соціоніки (яка описує динаміку іміджів, символів, орієнтацій політичних партій у залежності від психоемоційного запиту суспільства). Наш підхід базується на з'ясуванні впливу стратегічної функції політичної партії у виробленні політичного курсу та його впливу політичну символіку. Проте, вказана позиція вимагає як теоретичних, так і практичних доказів. Саме вирішенню цього питання й присвячено наше дослідження.

Об'єктом дослідження є специфіка трансформаційного розвитку політичних партій України у контексті їх символічної природи, вітчизняної та зарубіжної політичної практики.

Предметом дослідження є символи політичної партії як складова ії іміджу.

Мета дослідження полягає передусім в тому, щоб критично переосмислити й предметно переглянути існуючи концептуально-методологічні підходи до сутності принципу поділу влади й уточнити їх контексті з урахуванням специфіки України. Вказана вимагає від нас зосередити фокус дослідження на партійній фракції як функціонального елементу забезпечення процесу розробки й прийняття політичних рішень. 


\section{2. Методи дослідження}

Методологічна база дослідження побудована на використанні системного підходу, де імідж політичної партії подається як система вербальних та невербальних ознак, що впливають на свідомість й поведінку виборців; структурно-функціонального підходу-де система політичного іміджу політичної партії є частиною управлінського менеджменту партії, що забезпечує вербально-комунікативний дискурс між виборцями та керівництвом. У свою чергу, допоміжним $є$ використання синергетичної методології, оскільки сама по собі символічна ознака партії є елементом.

\section{3. Результати}

Наукова основа вивчення символів політичних партій виходить безпосередньо з їх місця та ролі та функцій у політичний системі або політичного досвіду через парламентську або політичну діяльність. Роль політичних партій у політичній системі будь-якої країни залишається значною й у де яких випадках вирішальною. Саме політичні партії забезпечують динаміку розвитку політичної системи, оскільки вони репрезентують інтереси громадян та виробляють стратегічний курс розвитку країни через виконання ними функції формування законодавчою та виконавчої влади. Причому, саме реалізація законотворчої ініціативи забезпечує вплив та формування політичною партією (через фракцію певної партії у парламенті) офіційної внутрішньої, зовнішньої політики та курсу розвитку країни. Серед найважливіших якостей, якими можна охарактеризувати політичну партію є також виховання політичної еліти країни, яка безпосередньо займається реалізацією передусім курсу партії (наприклад, програма «Україна для людей» Партії регіонів та В. Януковича, план-стратегія «Український прорив» ВО «Батьківщини» та Ю. Тимошенко). Отже, саме діяльність політичної партії формує у виборців та громадян стереотипи сприйняття певної політичної сили «як ефектної», «не ефективної», «захищаючої інтереси громадян» тощо. Одним із засобів вираження діяльності політичної партії й одночасно інструмент репрезентації політики певної партії є її символіка. Як відмічає відомий вітчизняний дослідник А. Тимашевський, партійні символи є одночасно відображенням програмних засада партії та її політичного курсу щодо формування соціально-політичних процесів [1, с. 43-44]. Разом з цим варто зазначити, що на цьому суто політологічні дослідження впливу партійної символіки на вироблення стратегічного курсу політичних партій й закінчуються. Навіть не зважаючи на намагання вітчизняних науковців виробити універсальну методологію подібних досліджень, спостерігається комплекс невирішених питань, серед яких найбільш гострими є проблема дослідження вибору партійної символіки, яка б повністю відображала курс політичної партії та вплив партійної символіки на електоральні орієнтації своїх виборців. Іншими словами, досліджень, які б вивчали, наприклад співвідношення синіх кольорів Партії регіонів з нанесенням українського прапору та курсу політики партії на євроінтеграцію; або вибір синіх кольорів ВО «Свобода» на той ж самий курс євроінтеграції, виняток-«Опозиційний блок», де синій колір та схожий дизайн літер з Партією регіонів слугує прикладом продовження політики колишньої політичної сили. Але, на ідеологічній арені й у свідомості громадян вказані політичні партії не асоціюється з євроінтеграційним курсом, а виступають гострими супротивниками навіть не зважаючи на спільну мету - євроінтеграційний курс України. Таким чином, не зважаючи на вибір політичною партією одних й тиж самих кольорів, сповіщення однакового політичного курсу розвитку країни - вони можуть виступати не союзниками, а гострими конкурентами й мати у свідомості громадян діаметрально протилежні кліше. Представлене, наприклад, й без того ускладнює вироблення універсальної класифікації політичних партій в Україні.

Вперше на вказану проблему звернув увагу фахівці з психології М. Люшер та політичної психології В. Неборякіна, які на дослідженні символів політичних партій Естонії довели вплив кольорів та символів у будь-якій сфері життя суспільства на нервову систему людини незалежності від статевого, расового, культурного, освітнього, соціального, політичного приладдя. 
На думку вчених, поєднання кольору та певних символів має дві якісні характеристики, перша 3 яких доводить, що політична партія як й будь-який інший «товар» має власну обгортку, стиль, функціональне призначення; друга - політична партія через свої символи встановлює не скільки комунікацію, а скільки «штамп у психіці» людини з метою асоціації в ії психіці певних образів, кліше, ярликів [2, с. 28]. Проте, на наш погляд, при дослідженні партійної символіки у контексті ії впливу на політичний курс партії не варто проводити ототожнення 3 психологічними засобами впливу на масову свідомість людини. Через те, відомий російський вчений К. Гаджиєв пояснював символічну природу політики як систему образів політичної реальності з виділенням двох полюсів (багатошаровість й багатовизначеність явищ), ми отримуємо парадоксальну ситуацію-політична символіка та політичний курс партії виступають не що іншим, як відображенням певної традиції, соціокультурних орієнтирів суспільства, й тільки потім оформлюються у «психологію кольору» [3, с.521-522]. Тобто, політичні символи виступають своєрідним ланцюгом між історичним досвідом та сучасним світом й несуть у собі зразки історичної пам'яті, яка через повторення дій, гасел, символів, надписів викликає у виборця почуттєве, а не маніпуляційне уявлення про політичний курс або політичні подію [3, с. 522].Наприклад, на логотипі Республіканської партії США у центрі логотипу знаходиться слон, який ототожнюється з історичним минулим партії щодо захисту прав поневолених та вільних підприємців (слон символізує міць партійних лав). Така політика знаходить своє відображення й у курсі політичної партії, яка віддає перевагу збройним вирішенням політичних конфліктів, що $є$ своєрідною демонстрацією воєнної міцності Сполучених Штатів Америки (війни у В’єтнамі й Іраку, вторгнення у Афганістан відбулися саме за правління республіканців); також, слон у логотипі республіканців має й інше значення - це захист трудового населення від інфляції та соціальних катаклізмів [4]. Партійний колір республіканців - червоний, доречі цей колір також використовують й комуністи в Україні та Росії (як символ Жовтневої Революції 1917 року), проте у версії Республіканської партії він означає рух вперед й збереження американських цінностей. У свою чергу, ідеологічні опоненти республіканців демократи у своїй символіці використовують віслюка як символ «попередження небезпеки» й соціально-політичного захисту звичайних робітничих. Неофіційний, але у той самий час загальноприйнятий колір партії-синій. Він символізує доброчесність і в той самий час слугує нагадуванням американцям про трагічні сторінки історії Громадянської війни між північчю та півднем у 1861-1865 роках (тобто, синій колір символізує «морально-духовну» травму суспільства); назване знаходить своє відображення й у політичному курсі цієї партії-впертість у позиціях, але впевненість у реалізації навіть не популярних політичних рішень [5, р. 229]. Таким чином, виборець у Сполучених Штатах Америки з логотипу та кольорів політичної партії може зробити висновок про іiї політичний курс на термін каденції у Конгресі. Дещо схожу гаму використовує Блок Петра Порошенко «Солідарність», неофіційний колір самої Солідарності-синя кольорова палітра, яка використовується переважно під час соціальних акцій, а офіційна символіка та дизайн політичної сили має біло-червоні кольори, які перекликаються 3 кольорами іншої політичної сили - Блоку Юлії Тимошенко. На наш погляд, запозичення цієї стратегії партійного розвитку слугує про те, що у свідомості електорату закріплюється кліше, що саме Солідарність $є$ наступницею БЮТу, бо кольори та гасла схожі, також й дизайн-спільний. Робиться це партійними будівниками лише з однією метою-залучити до своїх лав електорат іншої політичної сили.

Проте, у такому уявленні про партійну символіку мову можна вести й проїі маніпулятивний сенс, бо саме через символи у виборців формується образи та моделі поведінки. 3 цього приводу дослідник з політичних маніпуляцій Е. Доценко зазначає, що вибір кольору партійних прапорів та символів у політиці мають також й певну мету, і не завжди уособлюють в собі курс або ідеологію певної політичної сили [6, с. 122]. Наприклад, естонська Партія молодих реформістів у своїх кольорах використовує жовтий (лідерські амбіції, динамізм розвитку) 
та синій (у контексті розміреності та історичної пам'яті естонських борців за незалежність країни) [7, с.30-31]. Іншими словами, Партія молодих реформістів у своїх кольорах використовує вдалі моральні принципи та амбіції будь-якої партії, проте й той самий час, логотипом партії $є$ білка (невпевненість у власних діях, страх перед відповідальністю за власні дії) [7, с. 30-31]. Назване знаходить й своє відображення і в риториці цієї політичної партії, якої на думку естонських політологів якраз й бракує впевненості у реалізації власного політичного курсу (демократизм, реформування, реалізація європейських цінностей). Іншими словами, виборець цієї партії знаходиться в омані. 3 цього приводу, Е. Доценко також зазначає, що при розробці партійної символіки варто спочатку проаналізувати групу тих, на кого вона розрахована (передбачуваний електорат), а також провести необхідну корекцію символів, де варто також показати модель та курс партійної політики. У якості такого інструментарію дослідник пропонує при розробці символічного явлення світу враховувати:

- спонукачі мотиви певної форми діяльності (інтереси, ідеали, запити);

- засоби регулювання соціальної активності (сенсові, цільові, вірування, світогляд) - комунікаційні аспекти сприйняття символів (знання о стереотипах своїх виборців) - спосіб осмислення символів (звички, традиції) - психологічний стан («мода» на певний зразок поведінки) [6, с. 122-123].

На наш погляд, 3 наведеного виходить, що партійна символіка має не тільки свої функціональні ознаки, а також формує певний спосіб мислення, сприйняття дійсності, й виступає результатом соціального запиту населення на певну модель політичного курсу країни. 3 цього приводу варто навести думку провідного російського дослідника політичної символіки В. Попова та А. Цуладзе 3 приводу того, що будь-який політичний символ сам по собі вже виступає орієнтиром, програмним документом та засобом комунікації між всіма учасниками політичної дії; тобто, будь яка влада, чи політичний курс неможливі без символічного оформлення $[9$, с. 53]. Представлену логіку багато в чому доповнює вже згадуваний нами вітчизняний дослідник О. Тімошевський, який зазначає, що партійна символіка виконує також функцію політичної соціалізації суспільства, бо саме вона забезпечує процес інтеграції індивіда до певної моделі сприйняття політичної реальності з усіма її орієнтаціями та установками; також партійна символіка є своєрідним результатом впроваджених партією соціально-політичних змін, що у свою чергу відображає ціннісні і якісні аспекти політики [9, с.306]. Стосовно аналізу символіки українських політичних партій, то попереднє дослідження символіки політичних партій, які за результатами Виборів-2012 року сформували Верховну Раду України 7-го скликання показало наступне. Партія регіонів у своїх символах використовує державну символіку України, у середину якої вписано контури мапи нашої держави. Все це виконано на прямокутнику блакитного кольору (символізує доброчесність й гармонійний розвиток України [10]. Партія «Український демократичний альянс за реформи» у свої символіці використовує ім'я свого лідера екс-боксера В. Кличка, при цьому офіційного тлумачення символіки у партійних документах не надається, що дає нам підстави стверджувати, що єдиним символом політичної партії залишаються перемоги на боксерському ринзі її лідера. Стосовно політичної партії «Батьківщина», вона також не подає офіційного тлумачення партійної символіки. Разом з тим, партія використовує білий та червоний кольори у логотипі зазначено елемент у вигляді серця (що може символізувати «любов до правди»). Також офіційного тлумачення власної символіки не подає й Комуністична партія України, втім, вона активно використовує червоний колір та логотип Комуністичної партії Радянського Союзу, що у свою чергу символізували революційні перетворення та захист прав робітників (серп та молот). I нарешті, Всеукраїнське об'єднання «Свобода» також не подає трактування власної символіки, втім політична партія активно використовує синій колір на прапорах та малий Герб України Тризуб у формі схрещених пальців людини. Отже, стосовно впливу партійної символіки на вироблення політичного 
курсу країни українськими політичними партіями потребує додаткового вивчення, й саме цьому аспекти буде присвячено наші наступні наукові розробки.

\section{4. Висновки}

Таким чином, підсумовуючи результати дослідження ми дійшли наступних висновків. По-перше, символіка політичних партій у загальному сенсі являє собою межу між сподіваннями електорату на захист політичною силою їх інтересів та стратегічним курсом політики цієї сили. По-друге, вплив партійної символіки на психологію електорату залишається більш значним, ніж гасло або програма цієї партії, бо як нами вже було доведено у дослідженні, використання однакових кольорів та схожих програмних документів не може говорити про ідеологічну схожість цих політичних сил. По-третє, політичні партії України при виробленні власної символіки намагаються зобразити загальнолюдські цінності, які до політичного життя майже завжди не мають жодного відношення.

\section{5. Список літератури:}

1. Тимошевский А. В. Политические партии-символ формирования политического сознания / А. В. Тимошевский // Науковий вісник. Всеукраїнська асоціація молодих науковців. - Гуманітарні науки: історія, соціологія, політологія, психологія, мистецтвознавство. - 2002. - №4.-С. 41-46.

2. Неборякина В. Психологические аспекты политической символики // Менеджмент и кадры: психология управления, соционика и социология. - 2010. — №4. - С. 28-33.

3. Гаджиев К. С. Введение в политическую науку: учебн. для вузов / К. С. Гаджиев. - 2-е изд.-М.: Издательская корпорация «Логос», 1997. - 544 с.

4. Молчанов С. М. Политические партии США на современном этапе [електронний peсурс] // Режим доступу: http://samlib.ru/m/molchanow_s_m/uspoliticalpartiesatpresent. shtml

5. Hale J. The Making of the New Democrats. New York City: Political Science Quarterly, 1995. - $242 \mathrm{p}$.

6. Доценко Е. Л. Психология манипуляции. Феномен, механизмы, защита. — М., ЧеРо, Издательство МГУ,1997. - 344 с.

7. Неборякина В. Логотипы партий и ценностные установки политических движений // Менеджмент и кадры: психология управления, соционика и социология. - 2010. - №5.- - С. 29-34.

8. Цуладзе А. Большая манипулятивная игра / А. Цуладзе //- М.: Алгоритм, 2000. - $336 \mathrm{c}$.

9. Тимошевский А. Особенности символики политических партий // Наукові записки Інституту політичних і етнонаціональних досліджень ім. І. Ф. Кураса ВНАН України. - 2013 / 1 (63)-С. 301-309.

10. Символика Партии регионов [електронний ресурс] // Режим доступу: http:// partyofregions. ua/about/symbolics

\section{References:}

1. Tymoshevskyj A. V. Polytycheskye partyy — symvol formyrovanyia polytycheskoho soznanyia / A. V. Tymoshevskyj // Naukovyj visnyk. Vseukrains'ka asotsiatsiia molodykh naukovtsiv. - Humanitarni nauky: istoriia, sotsiolohiia, politolohiia, psykholohiia, mystetstvozn avstvo. - 2002. - №4. - S. 41-46.

2. Neboriakyna V. Psykholohycheskye aspekty polytycheskoj symvolyky // Menedzhment y kadry: psykholohyia upravlenyia, sotsyonyka y sotsyolohyia. - 2010. — №4. - S. 28-33.

3. Hadzhyev K. S. Vvedenye v polytycheskuiu nauku: uchebn. dlia vuzov / K. S. Hadzhyev. — 2-e yzd. — M.: Yzdatel'skaia korporatsyia «Lohos», 1997. — 544 s. 
4. Molchanov S. M. Polytycheskye partyy SShA na sovremennom etape [elektronnyj resurs] // Rezhym dostupu: http://samlib. ru/m/molchanow_s_m/uspoliticalpartiesatpresent. shtml

5. Hale J. The Making of the New Democrats. New York City: Political Science Quarterly, 1995. - $242 \mathrm{r}$.

6. Dotsenko E. L. Psykholohyia manypuliatsyy. Fenomen, mekhanyzmy, zaschyta. - M., CheRo, Yzdatel'stvo MHU,1997. - 344 s.

7. Neboriakyna V. Lohotypy partyj y tsennostnye ustanovky polytycheskykh dvyzhenyj // Menedzhment y kadry: psykholohyia upravlenyia, sotsyonyka y sotsyolohyia. - 2010. — №5. - S. 29-34.

8. Tsuladze A. Bol'shaia manypuliatyvnaia yhra / A. Tsuladze //—M.: Alhorytm, 2000. $-336 \mathrm{~s}$.

9. Tymoshevskyj A. Osobennosty symvolyky polytycheskykh partyj // Naukovi zapysky Instytutu politychnykh i etnonatsional'nykh doslidzhen' im. I. F. Kurasa VNAN Ukrainy. — 2013 / 1 (63)-S. 301-309.

10. Symvolyka Partyy rehyonov [elektronnyj resurs] // Rezhym dostupu: http:// partyofregions. ua/about/symbolics 